się być postponowana, gdyż ani Prezydent Federacji, ani obecny premier Nouri Al-Maliki nie są w stanie zaproponować rozwiązania, które w sposób definitywny i pokojowy rozwiązałoby ten palący problem. Przytoczone zostało również rozwiązanie wykreowane przez International Crisis Group, w którym postuluje się wprowadzenie proporcjonalnego podziału w administracji prowincji Kirkuku według formuly: 32-32-24-4 (Kurdowie, Arabowie, Turkmeni i chrześcijanie), odrzucające jednocześnie możliwość przeprowadzenia referendum w regionie. Autor wskazuje, iż przyjęte rozwiązanie federalne stanowi asumpt do kształtowania stabilności w tym rejonie świata, gdyż nie tylko Kurdowie stanowią czynnik potencjalnie separatystyczny, ale i szyici zamieszkujący południowo-wschodnie tereny przygraniczne. Przyszłość Iraku uzależniona została od polityki USA wobec tegoż państwa, jak również od funkcjonowania ,frontu antykurdyjskiego" uosabiającego politykę Turcji, Syrii oraz Iranu wobec Kurdystanu irackiego. Badacz kwestii kurdyjskich konstatuje „szanse powstania niepodległego Kurdystanu są niewielkie” (s. 329). Jednak postępująca szyityzacja na pohudniu państwa oraz powstanie nowego kraju, w którym dominowałby szariat, mogłyby zdaniem Autora przyczynić się do wsparcia przez USA niepodległości Kurdystanu, jako bufora bliskowschodniego. Konkluzją pozostawia kwestię niepodległości Kurdów jako wciąż otwartą jednak bliżej nie określoną w czasie.

W recenzowanej książce możemy doszukać się kilku powtórzeń. Wiele spośród omówionych w pierwszych siedmiu rozdziałach treści pojawiło się w podsumowaniu, które stanowi ostatni rozdział pracy, nie wnosząc jednak niczego istotnego do rozważań nad postawiony w tytule rozdziału pytaniem. Autor nie uniknąl również błędów w pisowni decydując się na używanie nazwy angielskiej dla stolicy RKI „Erbil’”. Według standardów nazw geograficznych opracowanych przez Komisję Standardów Nazw Geograficznych przy Glównym Geodecie Kraju, rekomendowana jest pisownia „Irbil”3. Rola państw Unii Europejskiej została zmarginalizowana na rzecz hegemonicznej pozycji USA i Turcji w regionie. Niemniej trud pracy włożony przez Krzysztofa Lalika w opracowanie ogromu materiałów (zwłaszcza prasowych) należy ocenić jako bardzo istotny. Ważnym jest również, że recenzowana publikacja wpisuje się w niszę, gdzie obok książki autorstwa Marii Giedz ${ }^{4}$, dostarcza polskiemu czytelnikowi aktualnych informacji na temat problemu kurdyjskiego.

Błażej GRYGO

Uniwersytet im. Adama Mickiewicza, Poznań

\title{
Marcin Nowacki, Prawne aspekty bezpieczeństwa energetycznego w Unii Europejskiej, Wydawnictwo Oficyna Wolters Kluwer Business, Warszawa 2010, ss. 472.
}

Treść książki podzielona jest na sześć rozdziałów, a każdy z nich składa się z kilku lub kilkunastu podrozdziałów. Objętość poszczególnych rozdziałów jest podobna. W książce zawarto wykaz skrótów i nazw wszystkich organizacji międzynarodowych i instytucji unijnych, które powstawały na przestrzeni lat w celu tworzenia polityki energetycznej na świe-

Nazewnictwo geograficzne świata. Zeszyt 2. Bliski Wschód, GUGiK, Warszawa 2004, s. 40-41.

M. Giedz, Kurdystan. Bez miejsca na mapie, Pelplin 2010. 
cie. W publikacji zawarto też listę kilkuset tytulów opracowań naukowych, z których korzystał Autor.

Celem opracowania jest przedstawienie analizy różnych aspektów problemu bezpieczeństwa energetycznego w oparciu o uregulowania prawne tworzone przez Unię Europejska. Poprzez systematyczną i szczególową analizę najważniejszych doktryn i aktów prawnych tworzonych na przestrzeni ponad pięćdziesięciu lat od początku dzialań na rzecz integracji europejskiej, Autor stwierdza, iż do tej pory nie zdołano stworzyć w ramach Unii Europejskiej jednolitego systemu prawnego i organizacyjnego, który w pełni zapewniałby bezpieczeństwo energetyczne państw czlonkowskich Unii Europejskiej. Na podstawie poglądów innych ekonomistów i specjalistów z dziedziny energii oraz znaczących wydarzeń historycznych, stwierdza się, iż zapewnienie bezpieczeństwa energetycznego jest obecnie dla świata i poszczególnych państw równie ważne jak zapewnienie bezpieczeństwa militarnego. Mówi się, iż posiadanie na swoim terytorium zasobów kluczowych surowców energetycznych takich jak ropa naftowa, gaz ziemny, ruda uranu, jest równoznaczne z posiadaniem groźnej broni. Doskonale zdają sobie $\mathrm{z}$ tego sprawę państwa, na terytorium których takie zloża są odnotowane. Państwa wykorzystują ten fakt do wywierania nacisku politycznego i ekonomicznego na odbiorców. Zjawisko to jest określone szantażem gospodarczym. Jest też sposobem na osiaganie wysokich zysków ze sprzedaży surowców. W książce opisuje się konkretne przykłady, kiedy surowce energetyczne wykorzystywano jako środki szantażu politycznego wobec innych krajów. Autor przytacza i opisuje dwa najpoważniejsze zdarzenia, nazwane kryzysami naftowymi, które spowodowały poważne zagrożenie dla bezpieczeństwa energetycznego na świecie. $Z$ powodów politycznych, kraje zrzeszone w OPEC nie tylko zmniejszyły wydobycie ropy naftowej, ale przede wszystkim kilkakrotnie podwyższyły cenę surowca. Ten kryzys wydarzył się w roku 1973, kolejny odnotowano w latach osiemdziesiątych. Jako przykład szantażu politycznego, Autor podaje Polskę, która znalazła się w poważnym kryzysie z ZSRR, kiedy na początku grudnia 1981 roku, ówczesny rząd ZSRR przesłał Polsce ultimatum. Jeżeli do pierwszego stycznia 1982 roku rząd Polski nie rozprawi się z ,Solidarnością”, zostaną obcięte dostawy gazu o polowę, a dostawy ropy naftowej nawet o 75\%. Stwierdza się, iż na skutek pierwszego kryzysu naftowego w latach siedemdziesiątych XX wieku, zapoczątkowany został rozwój prawa energetycznego. Zaczęly tworzyć się różne organizacje międzynarodowe, instytucje europejskie, w rezultacie doprowadzając do gwaltownego wzrostu liczby uregulowań i aktów prawnych odnoszących się do sektora energetycznego. Prawo energetyczne zaczęto definiować jako nową, osobną gałąz prawa. Zaczęli pojawiać się wyspecjalizowani w tej dziedzinie prawnicy. W recenzowanej publikacji przedstawiono, w jaki sposób, na przestrzeni lat i pod wpływem różnych zdarzeń na rynkach energii, tworzyla się polityka energetyczna Unii Europejskiej, jakie działania podejmowano przez szereg instytucji zajmujących się problematyką bezpieczeństwa energetycznego w celu znalezienia najbardziej odpowiednich środków, zapewniających bezpieczeństwo państwom członkowskim Unii Europejskiej. Należy zauważyć, iż Autor recenzowanego opracowania w sposób zrozumiały i wyczerpujacy poddaje analizie liczne akty i orzeczenia Trybunału Sprawiedliwości. Przedstawia pozytywne i negatywne skutki orzeczeń sądowych, dowodzi, jak skomplikowany jest proces ustanawiania jednolitego prawa w zakresie bezpieczeństwa energetycznego dla wszystkich państw członkowskich Unii Europejskiej, z uwzględnieniem takich aspektów jak ochrona środowiska, swoboda przepływu towarów, swoboda przepływu kapitału. Autor w poszczególnych rozdziałach książki przedstawia analizę i ocenę szeregu aktów prawnych. W rozdziale I poddano analizie prawne $\mathrm{i}$ instytucjonalne aspekty międzynarodowej współpracy energe- 
tycznej z uwzględnieniem zależności między bezpieczeństwem energetycznym a międzynarodową ochroną środowiska. Nie ulega wattpliwości, iż sektor energetyczny emituje najwięcej zanieczyszczeń do atmosfery niszcząc naturalne środowisko i wpływając na zmiany klimatyczne. Skutki tych emisji sq̨ odczuwalne na całym świecie. Zmiany klimatyczne stanowią pierwszorzędny problem całej ludzkości. Autor wskazuje instytucje i organizacje międzynarodowe zajmujące się tym problemem. Zwraca się uwagę na zaangażowanie w rozwiązywanie problemów ochrony środowiska Organizacji Narodów Zjednoczonych oraz OECD (Organizacja Wspólpracy Gospodarczej i Rozwoju). Kluczowe organizacje międzynarodowe, dążą do włączenia wszystkich państw świata do działania na rzecz przeciwdziałania zmianom klimatycznym. W tym celu organizacje te tworzą konwencje oraz postanowienia, regulowane są kwestie takich poczynań, jak sposób eksploatacji dna morskiego, budowa rurociągów, układanie kabli energetycznych, budowa infrastruktury energetycznej w strefach przygranicznych itp. Organizacje te rozstrzygają spory, jakie pojawiają się między państwami w tych kwestiach. Ponieważ nie wszystkie państwa zgadzają się z postanowieniami tych organizacji, dochodzi nieraz do poważnych konfliktów międzynarodowych. Wszelkie spory rozstrzygane są przez Międzynarodowy Trybunał Sprawiedliwości oraz przez Międzynarodowy Trybunał Prawa Morskiego. Wymienia się i poddaje analizie rolę Międzynarodowej Agencji Energii Atomowej (MAEA). Pod auspicjami Międzynarodowej Agencji Energii Atomowej przyjęto wiele umów międzynarodowych, dotyczących pokojowego wykorzystania energii jądrowej. Międzynarodowa Agencja Energii Atomowej zrzesza 151 państw (w tym Polskę). Autor zwraca uwagę na rosnącą rolę organizacji w świecie w zakresie bezpiecznego wykorzystania energii jądrowej. Przypisuje też ważną rolę Organizacji Narodów Zjednoczonych na polu ochrony środowiska. Wspomniana wcześniej organizacja MAE (Międzynarodowa Organizacja Energetyczna), powstała w roku 1974 jako reakcja na pierwszy kryzys naftowy, jaki mial miejsce w roku 1973. Skupia obecnie 28 państw (w tym Polskę). Celem OECD jest ochrona państw czlonkowskich przed ewentualnym kryzysem energetycznym oraz przeciwdziałanie powstawaniu takich kryzysów w przyszłości. W tym celu OECD utworzyła odpowiednie akty prawne, zobowiązujące państwa członkowskie do takich działań jak posiadanie rezerw interwencyjnych ropy naftowej w odpowiedniej wysokości, posiadanie środków ograniczania popytu, podejmowanie działań zmierzających do alokacji dostępnych dostaw ropy naftowej. W ramach Międzynarodowej Organizacji Energetycznej działa Agencja Energii Nuklearnej, zajmująca się sprawami dotyczącymi wydobycia $i$ handlu paliwami jądrowymi. W rozdziale przedstawiono także inne instrumenty takie jak Europejska Karta Energetyczna, która powstała w roku 1990. W ramach działania Europejskiej Karty Energetycznej podejmowane są kolejne próby uregulowania zasad globalnego rynku energetycznego na świecie. Omawiając cele i zasady działania wymienionych organizacji, Autor zaznacza ich duże znaczenie na rynku energetycznym i wciąż rosnącą rolę w tworzeniu bezpieczeństwa energetycznego ze szczególnym uwzględnieniem ochrony środowiska. Rozważając możliwość włączenia NATO w sprawę pilnowania bezpieczeństwa energetycznego na świecie, nie sądzi się, aby państwa członkowskie NATO były w chwili obecnej gotowe do zaangażowania się w kwestię bezpieczeństwa energetycznego. Dużą rolę w analizowanej kwestii przypisuje się grupie G8. W spotkaniach grupy G8 biorą udział wszyscy przywódcy państw czlonkowskich Unii Europejskiej. Rosja nie należy do najbardziej uprzemysłowionych państw świata, ale jako największy dostawca surowców energetycznych do krajów Unii Europejskiej, odgrywa istotną rolę na rynku energetycznym. W rozdziale pierwszym zwraca się także dużą uwagę na powstawanie na gruncie prawa międzynarodowego dokumentów dotyczących 
zrównoważonego rozwoju. Koncepcja przedstawia takie gospodarowanie zapotrzebowaniem na surowce energetyczne, aby zminimalizować negatywne oddziaływanie sektora energetycznego na środowisko naturalne i warunki życia społeczeństwa. Stale rosnące zapotrzebowanie na energię wymaga jednocześnie zapewnienia, że pozostanie ona powszechnie dostępna dla wszystkich użytkowników, a proces jej wytwarzania nie spowoduje zagrożenia dla środowiska naturalnego. Według Autora, przedstawione organizacje międzynarodowe, tworzące prawo energetyczne w celu zapewnienia bezpieczeństwa energetycznego, są przeciwwagą dla OPEC, która wywiera duży wpływ na rynek energetyczny na całym świecie. Celem OPEC jest przede wszystkim maksymalizacja zysków ze sprzedaży surowców energetycznych. Środki prawne tworzone przez Międzynarodową Agencję Energetyczną czy Traktat Karty Energetycznej mają jednak ograniczony zasięg. Twierdzi się, że w chwili obecnej brakuje realnej globalnej współpracy międzynarodowej na rzecz zagwarantowania bezpieczeństwa energetycznego. Współpraca ogranicza się często tylko do deklaracji podejmowanych na zebraniach. Współpraca w tym zakresie nasila się tylko wtedy, gdy pojawiają się poważne zakłócenia w ciagłości dostaw energii, lub gdy występują różnego typu kataklizmy klimatyczne. W celu zminimalizowania emisji zanieczyszczeń do atmosfery, konieczne są działania zastępujące takie surowce energetyczne jak węgiel czy ropa naftowa, surowcami niskoemisyjnymi. Niestety, związane jest to z koniecznością przebudowy infrastruktury energetycznej, co będzie powodem wzrostu cen za energię.

W kolejnym rozdziale analizowany jest proces kształtowania się polityki energetycznej Unii Europejskiej począwszy od Traktatu ustanawiającego Europejską Wspólnotę Węgla i Stali, a skończywszy na Traktacie z Lizbony. Stwierdza się, iż energia była jednym z głównych czynników mających wpływ na proces integracji gospodarczej, a to w dużym stopniu przyczyniając się do utrzymania pokoju i bezpieczeństwa w Europie. Sądzi się, iż przez dhugi czas nie było wystarczająco dużo dobrej woli ze strony państw czlonkowskich Unii Europejskiej, aby intensywnie tworzyć skuteczną politykę energetyczną. Dopiero w roku $2007 \mathrm{w}$ postanowieniach Traktatu z Lizbony, ujęto zasady polityki energetycznej Unii Europejskiej. Zwraca się uwagę na zależność między rosnącym uzależnieniem Unii Europejskiej od importu surowców energetycznych a postawą państw członkowskich wobec takiego stanu rzeczy. Skłoniło to instytucje unijne do utworzenia nowej koncepcji polityki energetycznej. W rezultacie można powiedzieć, iż zostały ustanowione podstawy prawne polityki energetycznej Unii Europejskiej poprzez Traktat z Lizbony. Wedhug Autora, skuteczność tej polityki będzie zależała wyłącznie od odpowiednich działań poszczególnych państw członkowskich Unii Europejskiej w tym zakresie. Jest wiele aspektów, które wywieraja wpływ na prawidłowe i efektywne wykorzystanie systemu aktów prawnych Unii Europejskiej, dotyczących bezpieczeństwa energetycznego. Twierdzi się, iż system ten jest spójny i komplementarny. Według Autora publikacji, dalsze starania państw czlonkowskich Unii Europejskiej, powinny iść w kierunku zmniejszania uzależnienia Unii Europejskiej od dostaw surowców z państw nieczłonkowskich poprzez promocję energii jądrowej, efektywności energetycznej oraz odnawialnych źródeł energii.

W rozdziale trzecim przedstawiono i poddano analizie konkretne dyrektywy oraz ich znaczenie w odniesieniu do poszczególnych rodzajów surowców energetycznych. Autor wskazuje na zalety poszczególnych aktów, ale twierdzi, iż brakuje odpowiednich przepisów zobowiązujących państwa członkowskie do utrzymania odpowiednich zapasów gazu ziemnego, zwiększenia mechanizmów solidarnościowych w przypadku zaistnienia zdarzenia, które mogłoby zakłócić dostawy surowców energetycznych. Autor twierdzi, iż 
niektóre definicje powinny być zmienione, np.: definicja ,poważnego zaburzenia dostaw” sprawia, iż mechanizm ten jest nieefektywny z powodu niskiego poziomu wrażliwości systemu solidarności między państwami w przypadku zakłóceń dostaw gazu.

Autor omawia kolejne akty prawne, w których podjęto tematykę konieczności oszczędzania energii, jej efektywnego wykorzystania oraz promocji odnawialnych źródel energii. Zwraca też uwage na rosnące znaczenie energii jądrowej. Sprawa ta zajmuje szczególne miejsce w porządku prawnym Unii Europejskiej. Odchodzi się natomiast od promowania korzystania z takich surowców jak węgiel, który podczas spalania wydziela najwięcej szkodliwych substancji. W związku z przydziałem państwom członkowskim Unii Europejskiej norm emisji zanieczyszczeń do atmosfery, utworzyl się unijny system handlu uprawnieniami do emisji gazów cieplarnianych. Według Autora publikacji, wokół tej sprawy jest obecnie dużo kontrowersji. Należy je eliminować poprzez szybkie wdrażanie aktów prawnych dotyczących pakietu klimatyczno-energetycznego.

Kolejnym problemem poddanym analizie jest wpływ ograniczeń swobód rynku wewnętrznego na bezpieczeństwo energetyczne Unii Europejskiej. W tej kwestii twierdzi się, iż nie ma w systemie prawnym Unii Europejskiej skutecznych środków prawnych. Rynki energetyczne są ograniczane poprzez interwencjonizm państw. Autor dowodzi, iż jest to zjawisko niekorzystne dla rynku pod wieloma względami. Trybunal Sprawiedliwości oraz Komisja Europejska wielokrotnie stwierdziły, że państwa stosujące interwencjonizm gospodarczy naruszają zasady rynku wewnętrznego i ograniczają swobodę przepływu towarów, kapitału oraz konkurencji. W rezultacie państwa zwiększają izolacjonizm państw czlonkowskich, a w konsekwencji nie sprzyjaja rozwojowi integracji europejskiej. Stwierdza się, iż w dalszym ciagu energia używana jest w poszczególnych państwach jako broń ekonomiczna, środek rywalizacji geopolitycznej. W publikacji zwraca się też uwagę na ważną kwestię, którą jest obowiązek zapewnienia wysokiego poziomu ochrony odbiorcom. Autor odnosi się do definicji bezpieczeństwa energetycznego, które powinno gwarantować każdemu dostęp do stałych dostaw energii po uzasadnionej cenie.

W rozdziale piątym omówiono środki, które proponuje Unia Europejska, a które powinny zwiększyć bezpieczeństwo energetyczne. Aby pojawily się satysfakcjonujące rezultaty, należałoby według Autora opracowania podjać szereg konkretnych działań. Duże znaczenie dla zwiększenia bezpieczeństwa energetycznego przyznaje się dywersyfikacji typów paliw i źródel dostaw. Otrzymywanie dostaw surowców z jednego państwa może narazić Unię Europejską na szantaż energetyczny i w rezultacie odcięcie dostaw. Autor publikacji ponownie zwraca uwage, iż stopień uniezależnienia Unii Europejskiej od dostaw surowców energetycznych jest zależny od efektywnego korzystania z surowców i energii elektrycznej, racjonalnego korzystania z energii. Wplyw ma na to odpowiednio dzialajaca infrastruktura energetyczna. Niezbędne jest jednak pełne zaangażowanie w realizację polityki energetycznej Unii Europejskiej wszystkich państw czlonkowskich, zgodnie z zasadą solidarności energetycznej Unii Europejskiej oraz wspólne dzialanie w celu wypracowania jednolitego stanowiska wszystkich państw Unii Europejskiej w kwestii zewnętrznej polityki energetycznej. Autor wyjaśnia znaczenie dokumentu ,Zielona Karta”, który zainicjował tworzenie zewnętrznej polityki energetycznej w 2000 roku. Ten oraz inne dokumenty zostaly opisane przez Autora w rozdziale szóstym, traktujacym o zewnętrznej polityce energetycznej Unii Europejskiej. Stwierdza się, że nie jest możliwe funkcjonowanie polityki energetycznej Unii Europejskiej bez realizacji unijnej zewnętrznej polityki energetycznej, opartej na solidarności państw członkowskich. Z tego względu Unia Europejska podejmuje współpracę na tej płaszczyźnie ze wszystkimi partnerami na rynku energetycznym. Są to 
kraje posiadające znaczne złoża surowców energetycznych. Szczególne znaczenie dla Unii Europejskiej ma współpraca z Rosją - głównym dostawcą gazu ziemnego do krajów Unii Europejskiej. Autor twierdzi, iż Unia Europejska jest jednym z najważniejszych odbiorców surowców energetycznych z Rosji, co wpływa na postawę Rosji wobec Unii Europejskiej. Sprzyja temu istniejąca już infrastruktura energetyczna między Rosją a Unią Europejską. Uważa się, że Unia Europejska powinna zachęcać Rosję do wypracowania nowej formuły prawnej współpracy międzynarodowej w zakresie energii. Wspomina się o współpracy Unii Europejskiej z OPEC. Uważa się, iż wspólpraca ta przebiega bez specjalnych zakłóceń, chociaż nie jest oparta na umowie międzynarodowej, ani innych porozumieniach. W publikacji przedstawiono najważniejsze aspekty wspólpracy energetycznej z innymi krajami na całym świecie. Wymienia się kraje, które nie są istotnymi producentami surowców energetycznych, ale ze względu na położenie geograficzne odgrywają szczególne znaczenie (np. Ukraina). Według Autora opracowania, wszystkie działania Unii Europejskiej, mają na celu ciągłe zwiększanie i zapewnianie bezpieczeństwa energetycznego na obszarze Unii. Można powiedzieć, iż jest to jeden z najważniejszych celów Unii Europejskiej. Stwierdza się, iż jedynie środki prawne oparte na liberalizacji rynku energetycznego, solidarności energetycznej państw członkowskich i unijnej zewnętrznej polityce energetycznej, mogą zagwarantować Unii Europejskiej bezpieczeństwo energetyczne w długoterminowym horyzoncie czasowym. Natomiast środki prawne oparte na interwencjonizmie gospodarczym, ograniczającym swobody rynku wewnętrznego, nie zapewnią takiego bezpieczeństwa. Sądzi się, iż bezpieczeństwo energetyczne jest utrzymywane na płaszczyźnie krajowej. Przyczyną sa zbyt ogólne rozwiązania prawne, przyjęte w ramach międzynarodowego porządku prawnego, majace ograniczony zakres pod względem przedmiotowym i terytorialnym. Zwraca się szczególną uwagę, aby środki zapewniające bezpieczeństwo energetyczne Unii Europejskiej były stosowane z zachowaniem najwyższej dbałości o sprawy ochrony środowiska $\mathrm{z}$ uwzględnieniem zagwarantowania racjonalnych cen energii oraz ochrony najsłabszych ekonomicznie odbiorców.

W podsumowaniu, Autor wymienia podstawowe elementy bezpieczeństwa energetycznego, którymi są: bezpieczeństwo dostaw energii, ekonomicznie uzasadniona cena energii, możliwość realizacji wartości i celów państwa, minimalnie negatywne oddziaływanie na środowisko. Jednocześnie dodaje, iż stosowanie racjonalnych cen energii i konieczność ochrony środowiska wiąże się ze stałym wzrostem konsumpcji energii na świecie, co w coraz większym stopniu uzależnia od surowców energetycznych. Należy zwrócić też uwagę na negatywne uwagi Autora dotyczące niektórych przepisów prawa energetycznego Unii Europejskiej oraz sposobów ich stosowania. Autor opracowania uważa, iż nadal należy usilnie pracować nad tworzeniem takich uregulowań prawnych, które w większym stopniu uwzględniałyby specyfikę rynków energetycznych poszczególnych państw członkowskich. Twierdzi się, iż obecny system prawa w zakresie bezpieczeństwa energetycznego jest dość spójny i komplementarny, ale z drugiej strony wymaga dalszych uzupełnień i dostosowań do zmieniajacej się rzeczywistości. Przedstawione i omówione w sposób zrozumiały przez Autora środki polityki energetycznej Unii Europejskiej, umożliwiają według niego osiagnięcie celu pod warunkiem pełnego zaangażowania się wszystkich państw czlonkowskich do ich realizacji. Poznaną publikację ocenić można pozytywnie. Autor wykazał profesjonalne podejście do omawianego problemu. Możliwie prostym i zrozumiałym językiem przedstawił czytelnikowi zagadnienia bezpieczeństwa energetycznego. Autor, w sposób wyczerpujący i przystępny dla przeciętnego czytelnika, przedstawił problematykę podstaw prawnych i środków koniecznych do realizacji celu, jakim jest bezpieczeństwo energetycz- 
ne Unii Europejskiej. O skali zagadnienia, świadczy fakt, iż w publikacji wymieniono kilkaset aktów prawnych, postanowień, traktatów, komunikatów, które tworzone byly na przestrzeni lat przez kilkadziesiąt organizacji międzynarodowych zajmujących się zagadnieniami energii. Należy podkreślić, iż pisząc pracę, Autor wykorzystał poglądy i stanowiska zawarte w innych opracowaniach naukowych. Temat, wybrany przez Autora, jest interesujacy ze względu na jego duże znaczenie dla pomyślności dalszego rozwoju naszej cywilizacji.

Czytelny i przemyślany układ książki zachęca do głębszej analizy zagadnień, a dodatkowe objaśnienia pojęć powoduja, że całość jest zrozumiała i nie zaskakuje trudnymi pojęciami.

Wojciech STANKIEWICZ

Uniwersytet Warmińsko-Mazurski, Olsztyn 